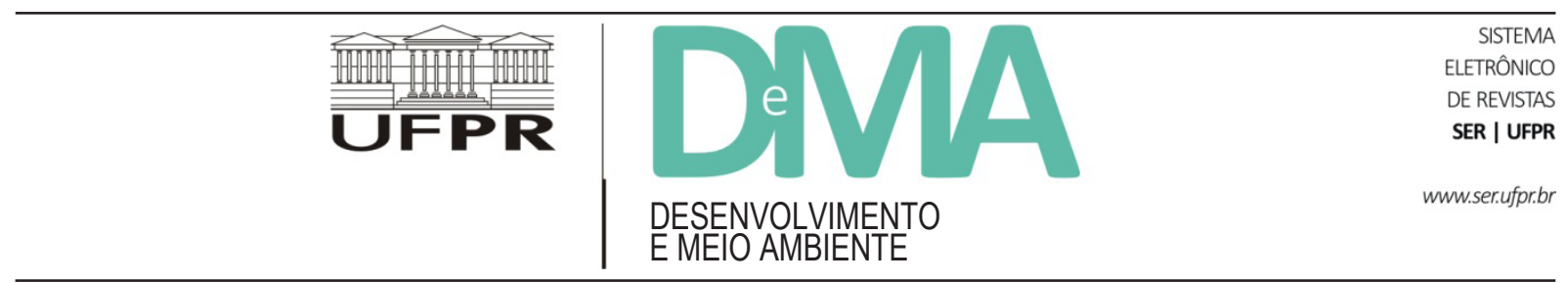

\title{
O desenvolvimento e as lógicas da mudança: a necessidade de uma abordagem holística*
}

\begin{abstract}
Claude RAYNAUT ${ }^{1}$
${ }^{1}$ Directeur de Recherche au Centre National de la Recherche Scientifique, Directeur de l'équipe Sociétés, Santé, Développement (C.N.R.S.), Université de Bordeaux 2, 146, Rue Léo-Saignat - 33076 - Bordeau Cedex.
\end{abstract}

A utilização de uma abordagem global das mudanças sociais para análise dos efeitos de um programa de desenvolvimento é justificável na medida em que este pretende ser o agente do "progresso" planificado. Quando aplicado a uma sociedade rural pré-capitalista, ele se apresenta muito frequentemente enquanto intervenção externa, indispensável para colocar em movimento estruturas "tradicionais", consideradas estáticas por natureza. A problemática da mudança é então percebida, em termos de reações e resistências às inovações trazidas de fora. A necessária desmistificação dessa representação equivocada da realidade passa pela identificação das diferentes lógicas atuantes no poderoso e complexo movimento de transformação em que a operação de desenvolvimento tem lugar. Movimento que encontra sua origem fora da operação e que prolonga seus efeitos muito além dela: só temporariamente é que esta operação se constitui em instrumento que intervém no curso do movimento. A análise de um caso concreto na região de Maradi, no Níger, e do Programa que foi ali implementado no período compreendido entre 1976 e 1988, permite ilustrar uma abordagem holística e demonstrar sua pertinência como método de abordagem interdisciplinar.

\section{I - A abordagem global da mudança}

Se existem sociedades rurais sobre as quais parecem se impor sem contestação e com urgência ações de desenvolvimento, são as da África Sahelo-sudaniana. Há mais de vinte anos, desde o período dramático da fome de 1973, aportes de ajuda financeira, humanitária e técnica sem precedentes vêm sendo mobilizados em socorro a essas regiões.

Trata-se de uma profunda e prolongada crise que impede a reprodução material nestas socieda-

\footnotetext{
*Tradução de Anamaria Aymore Bonin, antropóloga, Sandra Macedo, socióloga. Publicado originalmente em Cadernos de Desenvolvimento e Meio Ambiente, n. 1, 1994, p. 81-129.
} 
des. A manifestação mais espetacular dessa crise é a desertificação, o que atinge mais intensamente a imaginação popular e é mais explorado pelos meios de comunicação. Somente uma intervenção externa maciça talvez possa solucionar este problema. "Operações de desenvolvimento", comissões consultivas e o estabelecimento de coordenações, tais como a C.I.L.S.S. (Comité Inter-Etats de Lutte contre la Sécheresse au Sahel) e o Clube Sahel, proliferaram. Desde organizações financeiras nacionais e internacionais até as menores organizações não governamentais, todos têm se esforçado para promover e intensificar o combate ao que foi identificado como uma crise ecológica causada por um período de excepcional aridez e um rápido crescimento populacional. A abertura de poços, construção de áreas irrigadas, programas para a melhoria do plantio em solos áridos, reconstituição de rebanhos, reflorestamento, melhoria na utilização de materiais combustíveis foram algumas das ações empreendidas em escalas generalizadas pelos agentes empreendedores e das quais esperava-se uma restauração do equilíbrio nos sistemas de produção camponeses. Agora que as operações chegaram ao seu termo, chegou o momento de avaliar os resultados. Entre a maioria das pessoas há um sentimento de desencanto. Em 1986, foi organizada, pelo Banco Mundial em Oslo, uma conferência sobre o tema do controle da desertificação na zona Sahelo-sudanesa, Oeste-da África. Muitos colaboradores, assim como representantes dos países do Sahel, estiveram presentes. Se o resultado principal desse encontro não se traduziu num fracasso total, ele levou à conclusão de que um grande número das operações de desenvolvimento não haviam tido sucesso por falta de envolvimento das comunidades locais, independente da validade do ponto de vista técnico ou econômico. Uma nova palavra de ordem tem sido ouvida entre os peritos internacionais: a necessidade de se promover a participação camponesa. Embora essa nova abordagem possa ter suas limitações - geralmente ela se reduz a uma procura de receitas para mobilizar as populações (o que não traz nenhuma novidade!) -, pelo menos ela tem o mérito de traduzir uma tomada de consciência de que no interior das comunidades há uma dinâmica interna que não pode ser totalmente submetida aos imperativos de uma racionalidade externa, exceto por meios coercitivos.

Desde 1973, vozes minoritárias se expressaram, sugerindo que a crise no Sahel não poderia ser reduzida a fatores técnicos ou ecológicos. De acordo com esta interpretação, a crise representava uma ruptura total das bases econômicas e sociais sobre as quais funcionavam e se perpetuavam as comunidades rurais. Essa ruptura foi a consequência da dominação econômica e social pelos poderes colonial e neocolonial. ${ }^{1}$ Apesar de sua relevância geral, essa interpretação dos fatos tem conduzido a visões extremadas, entre elas o estudo Seeds of Famine, publicado há alguns anos, que é o melhor exemplo dessa postura. (Frank \& Chasin, 1981). Em primeiro lugar, este tipo de análise tende a subestimar as limitações objetivas às quais o sistema de produção se sujeita: a fragilidade do meio ambiente físico e natural da área Sahelo-sudanesa; a difícil realidade da crise climática causada pela falta de chuva e que afeta regiões inteiras do continente africano $^{2}$; o peso do crescimento populacional, que tem influenciado os sistemas de produção locais e que não pode ser ignorado, apesar de esse fenômeno possuir uma base histórico-social. Entretanto, a crítica mais radical que se pode fazer a tal interpretação da crise do Sahel (a de que ela é o resultado apenas de uma dominação externa) é de outra natureza: trata-se do fato de que a tese da "dominação" revela o desconhecimento de um aspecto fundamental concernente à evolução das sociedades locais, qual 
seja, sua capacidade para incorporar intervenções externas, nutrindo sua própria dinâmica interior, ao interpretá-las e adaptá-las aos seus próprios processos de mudança ${ }^{3}$. Seja do ponto de vista técnico ou das relações sociais, essas sociedades de maneira nenhuma devem ser vistas como instrumentos passivos de forças externas. Elas também contribuem para seu próprio desenvolvimento; são atores de sua história.

Não há mais lugar para uma abordagem simplista, seja ela naturalista, ecológica ou sociopolítica. Para se tentar entender os processos de transformação que estão ocorrendo nas sociedades Sahelo-sudanesas - e isto se aplica a um contexto que abrange qualquer sociedade rural em transição ${ }^{4}$ - a questão tem que ser abordada através de modelos analíticos complexos, que rejeitam interpretações lineares e unificadas e que sejam capazes de considerar um sistema global de interações, onde se combinam as restrições naturais, as forças do mercado, as práticas técnicas e as relações sociais e/ou simbólicas. Deve ser desenvolvido um modelo que represente a mudança de uma maneira integrada e holística, mas que vá além da simples constatação de que "tudo se junta", já que esta premissa básica, em si, não conduz a nada. Essa complexidade, portanto, tem que ser ordenada de alguma maneira, o que significa delimitar os campos pelos quais se articulam as interações e diferenciar, ou mesmo hierarquizar, os níveis de realidade onde estes campos se situam. O esboço de um tal modelo é possível com base em alguns princípios maiores.

\section{A dimensão objetiva e a dimensão das representações}

Este modelo deve, em primeiro lugar, exprimir uma constatação essencial, qual seja, a de que toda prática humana combina uma dimensão objetiva e uma dimensão das representações ${ }^{5}$. Para simplificar, pode-se dizer que uma prática não possui somente um valor instrumental, mas é também a expressão de uma imagem, uma representação da realidade. Assim, a cadeia de acontecimentos que determina mudanças num sistema social só parcialmente é baseada na causalidade material: intervêm, também, as relações simbólicas com as coisas e as pessoas, sofre a influência do jogo do imaginário e é tributária do exercício de um saber, enfim, de todos os elementos constitutivos de uma cultura. Para o homem, uma coisa conta tanto por ser "boa de se pensar" como "por ser boa de se comer". Este aforismo lapidar foi utilizado por Lévi-Strauss há muito tempo atrás para resumir a dimensão fundamentalmente dual de toda a atividade humana. Mesmo diante de mudanças drásticas das bases materiais do funcionamento de uma sociedade, como ocorre hoje no caso dos agrossistemas da zona Sahelo-sudaniana, onde a culpa da crise, em grande parte, é explicada pelo desequilíbrio físico entre recursos e necessidades, esta fórmula conserva toda a sua pertinência ${ }^{6}$. Também, numa situação como esta, são as normas e estratégias sociais que comandam o modo como os recursos naturais devem ser controlados e explorados e que orientam a manifestação das necessidades. Assim, num contexto natural idêntico (o do Sahel) a criação de animais pode se revestir das mais variadas formas, dependendo se ela é praticada por pastores nômades ou por agricultores sedentários; isto é, segundo o papel específico que lhes é atribuído e de acordo com os valores que lhes são imputados.

Como qualificar a relação entre as representações sociais e as realidades objetivas num processo global de mudança? Ao levantar esta questão, torna-se claro que nos distanciamos de uma abordagem macro-histórica, que se interroga sobre a 
gênese dos modos de produção e que dá primazia às determinações materiais sobre as superestruturas. Sem querer entrar no debate de pontos sutis que essa abordagem histórica suscita (o plano das representações sendo já constitutivo das forças produtivas, como bem mostrou Godelier), assinalamos apenas que a noção de determinação em última instância pelo econômico, especialmente quando aplicada numa espécie de materialismo mecânico, é de pouca ajuda para descrever e compreender as mudanças que se operam a médio prazo, numa sociedade inscrita no tempo e no espaço. A história contemporânea das sociedades rurais do Terceiro Mundo fornece, ao contrário, múltiplas evidências de que as transformações técnicas e econômicas são frequentemente tributárias de uma modificação prévia dos modos de pensar, do saber e de uma reorganização das relações sociais. Mas é também verdadeiro que a adoção de novos instrumentos e novas técnicas pode se tornar o ponto de partida de profundas transformações sociais e culturais ${ }^{7}$. Nesta escala de tempo, de algumas dezenas de anos, o que se pretende observar são fenômenos de interdependência e de ajustamento recíproco entre os elementos objetivos e os elementos imateriais que intervêm no funcionamento de um sistema social. O conceito-chave não é mais o de determinação, mas o da compatibilidade que deve existir entre as práticas materiais e o quadro conceitual e relacional que permite pensá-las e implementá-las. Esta noção implica a existência de uma margem de indeterminação que deixa espaço para que novos elementos possam ser incorporados. Num dado momento, podem se apresentar descompassos entre o estabelecimento de novas ideias e a retenção de velhas práticas, ou, ao contrário, entre sistemas de normas herdadas do passado e limitações materiais nunca antes experimentadas ${ }^{8}$. Isto cria uma situação de tensão e eventualmente de crise, da qual pode emergir um novo equilíbrio (embora não necessariamente e nem totalmente). Assim, a observação das modalidades concretas e específicas através das quais, numa dada situação, essas duas dimensões da realidade se afastam, depois se articulam e se ajustam, deve se situar no centro de todos os procedimentos da análise holística da mudança. O modelo de análise utilizado deve dar conta desta dualidade. Ao mesmo tempo, deve exprimir o fato de que no âmbito de uma dada cultura as representações se ordenam num sistema cuja coerência ultrapassa os setores de prática específica onde operam ${ }^{9}$.

\section{O conceito de reprodução e suas lógicas}

Na medida em que tenta dar conta, na sua complexidade, da dinâmica interna de um sistema social e de suas bases materiais, o estudo da mudança é necessariamente confrontado ao conceito de reprodução. Para que este se torne um elemento central de um modelo de análise dinâmico, duas condições devem ser preenchidas.

A primeira é que a noção de reprodução não seja assimilada à de repetição invariante, mas que seja vista como o processo dinâmico de perpetuação de uma entidade coletiva. Perpetuação que, na maioria das vezes, só pode se realizar à custa de transformações e de adaptações ${ }^{10}$.

A segunda condição é que o movimento geral, através do qual um sistema social se reproduz - manifestação da atividade de luta contra a entropia que caracteriza todo sistema vivo ${ }^{11}$ - seja considerado em toda a sua diversidade e complexidade, portanto, submetido a uma leitura que diferencie seus vários campos de aplicação. Dessa maneira, permite superar a noção de que tudo está e "tudo se junta" dentro de uma rede de interações generalizadas que possibilita isolar os campos de coerência que 
serão analisados tanto internamente como nas suas interconexões recíprocas.

As diversas lógicas específicas se definem cada qual em função de um "projeto", de uma "teleonomia" 12 que corresponde a um aspecto particular do processo global de reprodução.

A reprodução social é o campo onde se ordenam as relações sociais, onde se organizam as instituições e onde se confrontam as estratégias particulares. Assim, um sistema de parentesco ou um sistema político possuem seus princípios estruturais intrínsecos e demonstram propriedades organizacionais específicas, fontes de estabilidade e conservação do processo histórico. Esses sistemas contêm também suas contradições internas: linhas de fraturas que prefiguram e algumas vezes geram sua transformação. É impossível analisar a mudança sem levar em consideração essas lógicas sociais, sem identificar os atores nelas envolvidos, sem analisar as estratégias através das quais estes intervêm no sistema social ${ }^{13}$.

A reprodução material é o campo onde se combinam os fenômenos que formam a sustentação material do sistema social. Aqui, a articulação entre as condições do meio, os procedimentos técnicos empregados para sua exploração, as representações sociais subjacentes a estas técnicas e as formas de organização que permitem sua utilização, constituem um todo coerente e como tal deve ser analisado $^{14}$.

A reprodução demográfica corresponde ao domínio onde se articulam os fenômenos através dos quais uma população se perpetua enquanto entidade demográfica: provendo-se de uma progenitura, protegendo a integridade física de seus membros, regulando seus efetivos por movimentos de entrada e saída. Encontra-se aqui o ponto de convergência entre as condições do meio ambiente, os mecanismos biológicos próprios ao corpo humano, as práticas sociais referentes à saúde, à fecundidade, às migrações ${ }^{15}$.

Cada uma dessas lógicas deve ser analisada separadamente, tanto na sua coerência interna, que combina uma parte objetiva e uma parte relativa às representações, quanto nas contradições que abrigam. Entretanto, nenhuma deve ser considerada isoladamente, já que são inseparáveis umas das outras e todas contribuem para a reprodução geral da sociedade. De fato, o emprego do termo lógicas e não o de sistemas evidencia que não se visa aqui classificar os fatos em si em categorias exclusivas umas das outras, mas que se pretende identificar os campos de articulação que se superpõem, cada qual ordenado em função das necessidades que lhe são próprias, segundo uma finalidade específica. No plano da análise, isto significa que o mesmo objeto pode ser submetido às diferentes leituras. Assim, por exemplo, a força de trabalho utilizada no âmbito de um grupo social e que contribui para seu funcionamento poderá ser analisada, do ponto de vista técnico, sob o ângulo de sua integração no seio de uma dada cadeia de operações (um sistema de cultura, um itinerário técnico). Ela poderá ser analisada à luz das relações sociais de cooperação, de dominação, de dependência e de troca às quais ela se presta. Ela poderá ser, enfim, descrita como produto de processos biológicos que evidenciam práticas de gestão do corpo e da saúde e, a longo prazo, estratégias demográficas do grupo. Todas lógicas suscetíveis de serem, alternadamente, complementares, concorrentes ou até mesmo contraditórias.

Note-se que aqui não foi salientada, contrariamente ao que frequentemente se tem feito, uma esfera da reprodução econômica, porque a economia, no seu sentido abrangente, não corresponde a nenhum "projeto" específico. Ela representa somente uma das modalidades materiais através das quais 
as diferentes lógicas de reprodução se concretizam. Há somente um caso particular em que a economia se autonomiza e gera suas próprias finalidades: é o caso da economia baseada em trocas comerciais ${ }^{16}$.

\section{As lógicas externas}

As três lógicas acima mencionadas podem ser encontradas em qualquer sistema social, independentemente de sua forma de organização e das bases materiais de sua reprodução. $\mathrm{O}$ movimento de mudança pode ser desencadeado simplesmente pelo jogo das contradições mútuas dessas lógicas? Essa é uma questão fundamental à qual não saberíamos dar uma resposta universal. Entretanto, o que chama a atenção no exemplo das sociedades rurais do Terceiro Mundo - e na região africana Sahelo-sudanesa em particular -é o papel que pode caber às lógicas externas no desencadeamento dos processos de mudança. É nesse âmbito que intervêm notadamente as diferentes formas de dominação que foram introduzidas durante o período colonial e persistiram após as independências, por ocasião do movimento de formação de estruturas estatais. Seja qual for o peso dos fenômenos políticos e das estratégias de poder que se exercem em escala nacional ou internacional, a lógica de mercado é, sem dúvida, aquela que irá veicular as forças mais poderosas de mudança ${ }^{17}$. Através da introdução da moeda, da comercialização da produção local, que tem como retorno a compra de produtos industrializados, e do apelo à mão de obra assalariada, as exigências de troca mercantil perpassaram as sociedades camponesas locais, introduzindo relações de dominação ou de contradição às lógicas que presidiam até então a produção, a circulação de bens materiais e a alocação da força de trabalho ${ }^{18}$.

\section{Para um esquema de análise da mudança}

O esquema de análise proposto na Figura 1 resume, de uma forma gráfica, a combinação destes três princípios de construção. Evidencia a articulação entre fatores externos e dinâmicas internas, mostrando que se trata de dois planos complementares associados dentro de um único sistema global. Ao mesmo tempo, ordena o movimento geral das interações através das quais ocorre mudança nos diversos campos lógicos, que são, ao mesmo tempo, distintos uns dos outros pela teleonomia em que se baseiam e estreitamente solidários entre si. Além disto, marca claramente o lugar central ocupado pelas produções não materiais ou relativas ao plano das representações e ideias, colocadas tanto como constitutivas de cada uma das lógicas específicas quanto como campo particular com sua coerência e dinâmica próprias.

Por mais geral que seja este modelo, ele pode ter uma utilização prática. Especificamente, clarifica o problema das relações que se estabelecem entre um programa de desenvolvimento e a sociedade rural à qual se aplica. Pode-se justificar o uso de uma abordagem global da mudança para analisar os efeitos de um tal programa na medida em que este pretende ser o agente de uma transformação planificada e orientada no sentido do "progresso". Mais do que isto, quando se aplica a sociedades rurais pré-capitalistas, é usualmente concebido como o elemento de intervenção externa indispensável para colocar em movimento uma estrutura "tradicional", considerada como inerentemente estática - e que, portanto, coloca todo o peso de sua inércia em oposição a esta pressão exógena. Nesse contexto, a problemática da mudança é apresentada em termos de reações, de resistência às inovações trazidas de fora ${ }^{19}$. As soluções que procuram vão no sentido de 


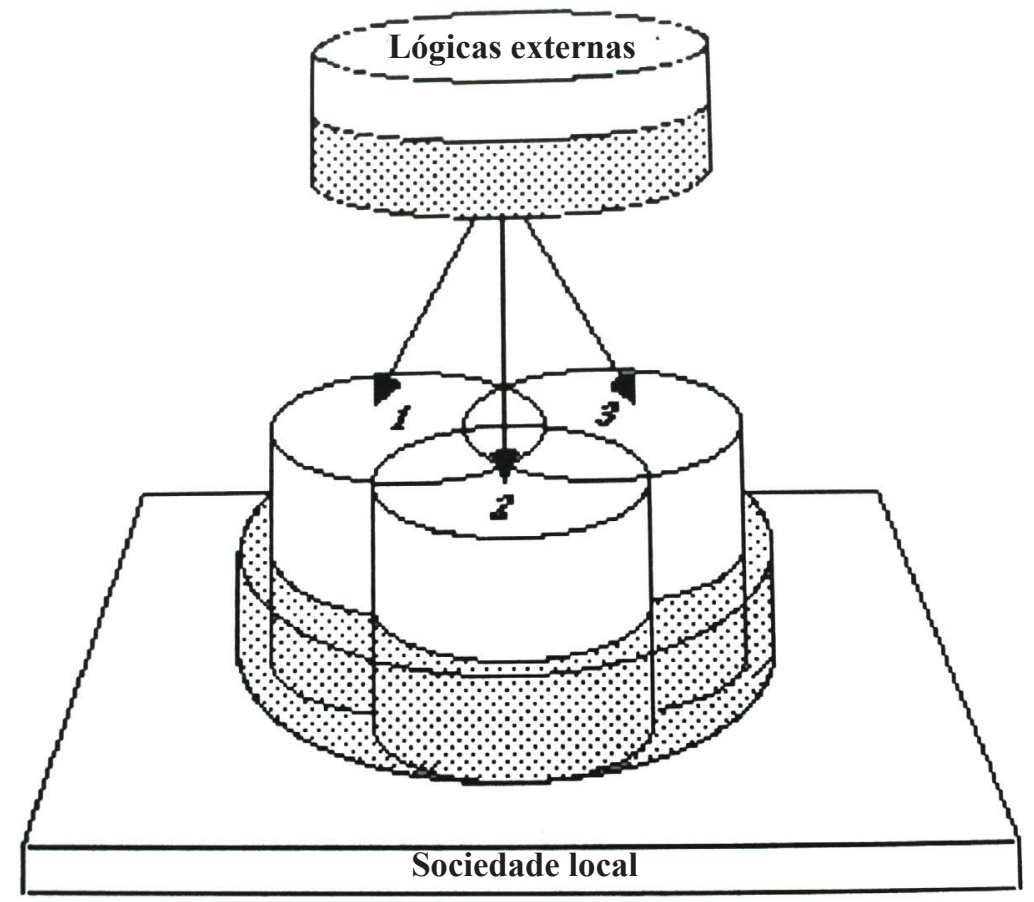

\section{Lógicas da reprodução: 1 - demográfica \\ 2 - social \\ 3 - material}

\section{Campo das representações}

FIGURA 1 - Esquema global da mudança.

uma superação dos bloqueios, de uma pedagogia que permita a "participação das populações". O que gostaríamos de defender neste texto é a ideia de que tal representação da realidade é inaceitável, na medida em que se constrói a partir de uma imagem artificialmente cristalizada das sociedades rurais, na medida em que abstrai a ação do desenvolvimento do possante e complexo movimento de transformação no qual se insere. Movimento que se originou fora dela e que prolonga seus efeitos bem além dela: só temporariamente é que tal ação se torna instrumento desta transformação. Reduzir a análise de uma intervenção de desenvolvimento a um problema binário de ação e reação leva a se mascarar questões bem mais essenciais.

Algumas dessas questões dizem respeito à maneira pela qual intervenções planejadas de fora se articulam com dinâmicas internas já em movimento, isto é, referindo-se ao modelo acima proposto, com os movimentos de ajustamento aos quais se submetem as três lógicas fundamentais que distinguimos. Tem sido usual que a ação de desenvolvimento se centre no campo da reprodução material e, mais especificamente, nas atividades de produção primária (agricultura e criação). Essas atividades já passavam por fortes perturbações no momento do lançamento 
do programa de desenvolvimento, o que se constitui justamente na justificativa de seu financiamento. Neste caso, o problema não é, evidentemente, o de vencer uma inércia, mas o de contribuir para se resolver uma crise técnica, ecológica e econômica com a qual a sociedade local se defrontava e a qual já tentava responder com seus próprios meios. Além disto, uma vez que os diferentes domínios da reprodução são estreitamente ligados, é pertinente questionar em que nível a intervenção externa interfere nas outras dimensões da mudança, e, em particular, que tipo de suporte ou, ao contrário, de entrave, constitui para as estratégias sociais internas das comunidades camponesas. Isto pode ser traduzido nas seguintes questões: a que interesses serve tal intervenção? A que grupos ou categorias esses interesses correspondem e que evoluções sociais são assim aceleradas ou freadas? Neste contexto, também não se deve negligenciar o domínio da reprodução demográfica (os fenômenos de crescimento populacional, enfermidades e movimentos da população), que intervém no conjunto e no aval de todo sistema de produçãa ${ }^{20}$.

Quanto à própria intervenção de desenvolvimento, seria um equívoco abstraí-la de seu contexto, considerá-la como portadora de uma mera racionalidade técnico-econômica e colocá-la como neutra em relação aos processos de mudança social. Ao contrário, um mínimo de recuo temporal incita a vê-la como um momento particular de uma longa história: a história das relações entre as comunidades locais e a sociedade global. Qualquer intervenção levada a cabo aqui e agora se inscreve nas lógicas políticas e econômicas de longo prazo, da qual ela se constitui em instrumento transitório. Peritos estrangeiros podem ter a ilusão de construir algo de novo, começando deste novo, mas os agentes nacionais e os camponeses locais partem de uma experiência que reinsere as iniciativas presentes no contexto do seu passado e que produz em cada ator uma certa repre- sentação dos embates em curso. Não se trata, aqui, de fazer um julgamento de valor sobre esta situação, mas de identificar as questões que são pertinentes ao problema global da mudança. A este respeito, parece indispensável uma análise das lógicas, explícitas e implícitas, que operam num programa de desenvolvimento e sobre a forma como elas se articulam com os movimentos históricos mais amplos.

\section{II - O caso de Maradi}

Para ilustrar esta análise geral e torná-la mais concreta, tomaremos como exemplo a situação observada numa região geográfica precisa. Trata-se da comunidade camponesa de Haussa, no Maradi, região do Níger. As informações aqui apresentadas se constituem apenas num resumo bem sucinto de resultados obtidos ao longo de um programa de pesquisa interdisciplinar, cujas conclusões detalhadas podem ser encontradas em outras publicações (Grégoire, 1980; Koechlin, 1980; Raynaut, 1975; Raynaut, 1980; Raynaut et al., 1988; Stigliano, 1980). Este caso apresenta um particular interesse porque traz elementos para uma análise global do funcionamento de sistemas agropastoris locais e dados que permitem avaliar os efeitos de um projeto de desenvolvimento financiado a partir de 1976 pelo Banco Mundial ${ }^{21}$.

Retomemos o modelo de leitura dos fatos acima esboçado e sua distinção em diferentes lógicas.

\section{A reprodução material e as lógicas da produção agropastoril}

Para se compreender os problemas que as comunidades camponesas da região de Maradi enfrentam e para examinar as evoluções em que 
estão envolvidas, deve-se tentar compreender as mudanças que intervieram nos princípios de funcionamento dos sistemas de produção agropastoris. Para isto, pode-se resumir brevemente a história da região nas últimas décadas.

Entretanto, antes de considerar a questão em termos de mudança, deve-se primeiro reconhecer os limites ambientais inerentes àquela região subtropical árida. De uma maneira geral, pode-se dizer que a característica mais importante dos sistemas agrícolas locais é a sua capacidade de manutenção de um equilíbrio durável do seu meio físico e natural, recorrendo a elementos exteriores de maneira limitada. Dado o contexto bastante particular dessa região, repercussões importantes daí advieram.

Primeiramente, a relação direta entre a produtividade agrícola e uma pluviometria aleatória e baixa colocava no primeiro plano das estratégias produtivas os objetivos de segurança. Na escolha de variedade de plantas, das práticas de cultivo e de criação de animais, o objetivo central não era maximizar os rendimentos por unidade de superfície ou por cabeça quando a chuva era satisfatória, mas tendiam a assegurar um mínimo de produção para a eventualidade de uma seca.

Em segundo lugar, a importância crítica de se manter o potencial de fertilidade de solos geralmente pobres e frágeis levava, mais do que em outros lugares, a uma necessidade de compensá-los, após o uso para cultivo, com restituições destinadas a restabelecer o equilíbrio perturbado. Estas provinham do ecossistema local, pela colocação da terra em repouso ou destinando-a a pasto, pela rotação e associação de culturas.

Em virtude desses limites ambientais, a prática de cultivo necessitava de um modo de exploração flexível e adaptável que permitisse a regeneração natural dos ecossistemas. Com algumas variações locais (Raynaut, 1984), essa dupla lógica de minimi- zação da pressão sobre o espaço e redução do risco dominava as práticas técnicas nas suas modalidades mais concretas. É ela que permite interpretar a maioria das escolhas tecnológicas efetuadas então pelos agricultores (mobilidade espacial, baixa densidade de sementes, instrumentos utilizados, combinação de culturas).

Entretanto, não se trata de maneira nenhuma de um determinismo do meio natural, já que outras opções técnicas são compatíveis com o contexto ecológico da área Sahelo-sudanesa e podem ser encontradas de forma marginal em outras localidades da região do Maradi, especialmente no caso das agriculturas peule e bouzou, que se baseiam numa associação estável com a produção animal (Nicolas, 1962; Diarra, 1979). Em última análise, a coerência específica da agricultura Haussa repousava numa articulação entre limitações materiais e opções sociais, opções que colocavam muito mais peso na gestão da força de trabalho e na maximização de sua produtividade do que na gestão da terra e de seus recursos (Raynaut, 1984). Esta escolha se origina no âmbito de uma outra lógica, qual seja, a lógica da reprodução social, o que retomaremos posteriormente, mas pode ser também percebida como uma das chaves do funcionamento do agrossistema do ponto de vista de sua própria coerência interna. Em resumo, pode-se dizer que se realizava assim uma harmonia durável, embora nem sempre imune a choques e crises, entre práticas técnicas e objetivos não materiais em que a preocupação maior era, mais ou menos diretamente, de ativar e mobilizar o tecido social. Um exemplo do peso das estratégias sociais sobre as práticas técnicas é encontrado entre os agricultores mais ricos da região de Maradi que, por longo tempo, preferiram empregar grande número de trabalhadores, em vez de mecanizar a exploração de suas terras, já que assim mantinham a clientela de quem sua popularidade dependia. 
Hoje, essa descrição do sistema de produção local está, evidentemente, defasada, porque a agricultura passou por uma evolução radical nas últimas décadas, que se traduz numa crise do modo de exploração extensivo da terra. A evidência mais clara dessas mudanças está na transformação espetacular das condições de ocupação do espaço, o que se constata ao se comparar fotografias aéreas tiradas com várias dezenas de anos de intervalo (Stigliano, 1980). Assim, observa-se, em escala regional, uma saturação da presença humana nas áreas de solo de dunas favoráveis a uma agricultura leve, ao mesmo tempo que se opera, em escala local, uma reorganização completa das estruturas dos territórios, reorganização esta marcada pela aparição de vastos setores de cultura permanente e pelo desaparecimento dos capoeirais (Raynaut, 1983). Esta pressão elevada sobre o espaço já é o resultado de um movimento complexo, onde os efeitos do crescimento demográfico se combinam com as limitações e exigências geradas pela inserção na economia de mercado. (Raynaut, 1988). Salientemos aqui que, através destas transformações fisiográficas, é a própria lógica interna dos agrossistemas que se afeta, essencialmente no que tange ao estatuto da terra: ao mesmo tempo que seu uso se estabiliza, surge a necessidade de lhe garantir uma gestão racional (em particular pelos cuidados deliberados com a manutenção de sua fertilidade). Esta mutação se acompanha de uma crise grave, acentuada pela ocorrência de choques climáticos sucessivos e que se traduz num esgotamento dos solos, numa queda da produtividade agrícola e na insegurança alimentar crônica. É evidente que o sistema de produção local atingiu um patamar agrotécnico $^{22}$ além do qual não pode conservar os mesmos princípios de funcionamento.

Como resultado disso, duas exigências se impuseram: dar prioridade à gestão da terra e aos seus recursos e utilizar regularmente elementos exteriores ao ecossistema local para recriar as condições de uma exploração durável do meio natural.

Quando confrontados a tais desafios, os agricultores não permanecem, de modo nenhum, passivos. Eles criam e experimentam novas práticas tecnológicas: estocagem massiva de hastes de milheto para alimentação animal (as superfícies em repouso que serviam para pastagem praticamente desapareceram); produção de esterco; proteção sistemática de certas árvores (tem-se testemunhado notadamente um crescimento espetacular da cobertura vegetal dos vilarejos); diversificação de espécies de plantas e variedades cultivadas; adoção de instrumentos de trabalho utilizados de grupos étnicos vizinhos (Raynaut, 1984) e aquisição de insumos modernos. São novas formas de articulação dos fatores de produção que estão sendo desenvolvidas, o que já é objeto de observações técnicas detalhadas (Le Gal, 1984).

Ao lado dessa evolução das práticas agrícolas, todo o conjunto de relações não materiais através do qual a natureza é pensada está sendo redefinido. O exemplo mais marcante disso é a emergência da apropriação privada não só da terra, como também da sua cobertura vegetal. Visto num contexto mais amplo, é toda a atitude em relação à atividade agrícola que está mudando. O orgulho de desbravar e destocar a terra e de cultivá-la com seu braço, ajudado pela parentela, cede lugar agora ao do camponês que, ano após ano, cultiva os mesmos campos e se esforça por tirar deles, de uma forma durável, os melhores frutos, através da implementação de uma gestão apropriada - inclusive, sempre que possível, incorporando elementos adquiridos no mercado (fertilizantes, produtos fitossanitários, sementes selecionadas, etc). No final das contas, são as finalidades sociais da agricultura que se transformam, 
passando progressivamente da gestão dos homens para o controle das coisas.

Fica claro, portanto, que o impacto de um programa de desenvolvimento rural tem que ser avaliado no contexto dessa transformação radical da lógica do sistema de produção agropastoril. Em relação a Maradi, nos deteremos em duas constatações principais.

A primeira é que neste caso a intervenção externa não pode ser de forma nenhuma considerada como tendo tido um papel motor na evolução que acaba de ser descrita. O sucesso da difusão de determinados aspectos técnicos relativos à intensificação do cultivo (utilização de outras formas de tração, uso de produtos fitossanitários, fertilizantes, etc.), está estreitamente relacionado ao nivel de contradição já atingido pelo sistema de produção camponês. Isto pode ser verificado historicamente em tentativas mais antigas para difundir certas técnicas novas que ficaram praticamente sem efeito enquanto o espaço podia ser utilizado sem parcimônia e os modos antigos de mobilização da força de trabalho (cooperação, alianças políticas, dependência familiar) conservavam o seu vigor, até meados dos anos 60. De fato, isto também é confirmado por uma comparação espacial. Mesmo hoje em dia, as diferenças observadas entre um vilarejo e outro na utilização de tais técnicas estão ainda muito relacionadas aos problemas específicos de cada um deles: nível de disponibilidade de terras, tipos de solo e evolução da fertilidade (Raynaut et al.,1988). Por último, em Maradi, como em qualquer outro lugar, uma observação acurada das práticas agrícolas mostra que as novas técnicas, ao serem adotadas, são reinterpretadas pelos agricultores em função de seus objetivos próprios - distintos dos objetivos dos engenheiros agrônomos - e que, longe de produzirem conturbações radicais, se inserem numa dinâmica preexistente. Por exemplo, os fertilizantes são utilizados em setores específicos do território disponível, aqueles onde as técnicas locais de fertilização não se aplicam. Outro exemplo: contra todas as recomendações dos agentes de extensão, a associação de espécies diferentes sobre uma mesma parcela continua a ser praticada, ainda que as variedades utilizadas sejam selecionadas pela pesquisa.

A segunda constatação relativiza a primeira na medida em que mostra que a intervenção de desenvolvimento, se não determinante, é suscetível a influenciar de forma significativa as evoluções em curso, seja orientando, acelerando ou freando. O mapa a seguir, que apresenta a difusão dos fatores de produção modernos na região de Maradi, mostra, claramente, o efeito da difusão a partir da localidade principal onde estão implantados os serviços centrais do projeto de Maradi e da qual partiram todas as iniciativas de desenvolvimento rural nas últimas décadas.

A ação de desenvolvimento não deixou de ter resultados. No entanto, seu impacto reflete também o modo de funcionamento da estrutura encarregada de empreendê-la: particularmente, sua dependência em relação a uma burocracia urbana que mede, com frequência, a intensidade de seus esforços em função inversa da distância dos deslocamentos que deve efetuar. Mas a difusão técnica não tem apenas uma dimensão quantitativa. Não se deve subestimar as consequências consideráveis que as opções técnicas adotadas a partir de um programa de desenvolvimento podem exercer sobre as possibilidades das comunidades locais encontrarem respostas para seus problemas específicos. Assim, em Maradi, entre os vilarejos que apresentam grave penúria fundiária, o nível de adoção de novas forças motrizes na agricultura depende largamente do tipo de instrumentos propostos: se é proposto um equipamento pesado, movido à tração bovina, rentável unicamente sobre superfícies extensas e, portanto, 


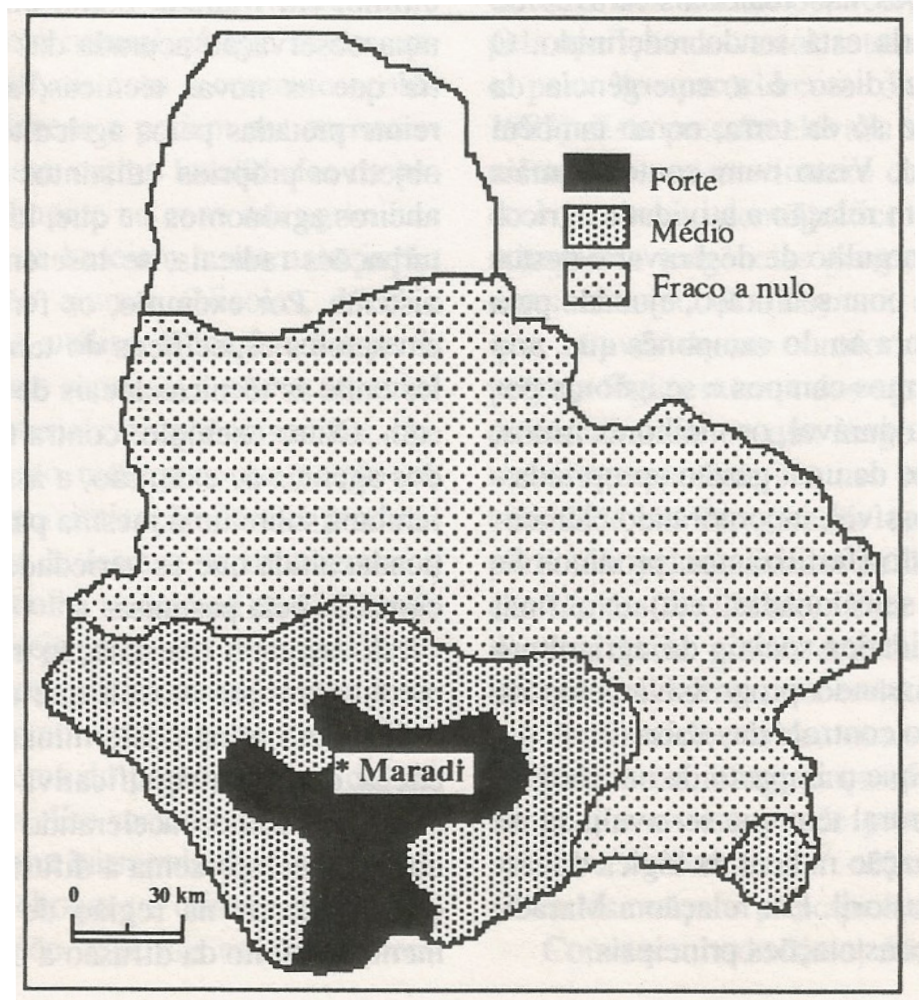

FIGURA 2 - Nível de difusão dos insumos (culturas à tração abnimal e mecânica e fertilizantes).

inadaptado a uma situação onde a terra é escassa ou, ao contrário, um equipamento leve, movido à tração asina, que responde bem às necessidades das explorações menores.

Este exemplo ressalta que as escolhas técnicas efetuadas no quadro de um programa de desenvolvimento - a partir de critérios de rentabilidade e de eficacidade frequentemente bem diferentes dos critérios dos agricultores - são suscetíveis de bloquear a dinâmica potencial de evolução das práticas agrícolas camponesas.

Em última análise, essas observações mostram que as mudanças técnicas operadas nas comunidades camponesas locais são fruto de uma transformação de seu sistema de produção. Esta evolução é uma expressão também do peso de limitações externas que ali têm atuado longamente - pressões do meio natural, de ordem demográfica e econômica - e os movimentos internos de ajuste que suscitam ou favorecem. É na dinâmica possante destas transformações que se inscreve a operação de desenvolvimento. Se ela pode, numa certa medida, produzir uma inflexão no seu curso (para frear ou acelerar), não se constitui, de forma nenhuma, num motor deste processo. Como foi dito antes, o problema principal aqui não é absolutamente o da oposição da sociedade camponesa haoussa às inovações oriundas de fora, mas da capacidade do programa de desenvolvimento de intervir, de modo adequado, no âmbito de uma crise. Deve-se 
constatar, a este respeito, que a concepção inicial do Projeto Maradi estava completamente defasada em relação aos problemas que se colocavam em meados da década de 1970. Enquanto as preocupações fundamentais dos agricultores tinham a ver com a penúria crescente do espaço, com a insegurança agravada pela degradação das condições climáticas e a baixa de suas rendas, o programa de difusão técnica tinha como objetivo central o aumento da produtividade agrícola, através da utilização de insumos caros. Além disto, mesmo que a ameaça aos recursos naturais impusesse a necessidade de sua gestão comum por parte dos seus diferentes utilizadores - habitantes das vilas que se tornaram concorrentes no que diz respeito ao acesso às terras cultiváveis, agricultores, pastores e lenhadores, todos cobiçando as últimas reservas disponíveis -, nenhum tipo de planificação foi proposto. As práticas extensionistas exerciam-se exclusivamente em nível individual, através de jovens que não hesitavam em sair de suas comunidades de base para serem levados aos centros de formação onde aprenderiam a gerir "racionalmente" uma exploração agrícola. Não foram considerados nem a posição social destes camponeses extensionistas em suas comunidades de base, nem as contradições que a aplicação de certos conselhos - que lhes foram prodigiosamente transmitidos - pudessem suscitar no confronto com os interesses coletivos das comunidades (notadamente no que concerne às superficies necessárias para rentabilizar o material de tração), nem se levava em conta as soluções que os próprios agricultores se esforçavam por encontrar. Sob estes diferentes pontos de vista, o programa de ação do Projeto de Maradi passava ao largo, desde seu início, dos problemas mais cruciais que deveria ter tentado resolver. Veremos mais adiante que isto não é fruto de um diagnóstico prévio incorreto, mas do efeito perverso da lógica institucional a qual obedeciam aqueles que o haviam concebido: as agências de financiamento e os poderes públicos.

\section{A lógica da reprodução demográfica}

Os fatos evocados até aqui sugerem, por si próprios, que a análise da mudança não pode ser esgotada no enfoque exclusivo do campo da reprodução material. Assim, é impossível explicar a crise agrária descrita sem referência à influência exercida pelo crescimento demográfico. Num período de vinte anos, a taxa anual média de crescimento das superfícies cultivadas na região de Maradi foi de $3 \%$, exatamente a mesma da população (Stigliano, 1980). Certamente o aumento populacional por si só não explica a saturação atual do espaço agrícola. Esta é também resultado do aumento na demanda de produtos agrícolas causada pela expansão das culturas comerciais e pelas "punções" econômicas realizadas sobre o mundo rural (Raynaut, 1975). Não obstante, o fato de que a população agrícola da região tenha dobrado nos últimos vinte e cinco anos obviamente exerceu uma grande pressão sobre a terra e, como consequência, sobre o funcionamento dos agrossistemas. Isto não significa que a vinculação entre o crescimento populacional e a evolução das condições de exploração do espaço seja tão mecânica como eventualmente se sugere. Não há um ponto de saturação absoluto de pressão humana e animal e os efeitos serão diferentes segundo as lógicas · internas dos agrossistemas sobre os quais ela se exerce. Assim, a escassez crescente de espaço não induziu algumas categorias de agricultores a se voltar para práticas intensivas, como alguns supunham (Raulin, 1967) mas, ao contrário, para práticas cada vez mais extensivas (Raynaut et al., 1988).

Uma coisa é constatar o crescimento populacional e reconhecer suas vinculações complexas com 
a evolução das condições materiais da exploração do meio ambiente, outra é analisar a lógica interna do fenômeno. Na realidade, há muito poucos elementos objetivos nesse campo de pesquisa. No máximo, pode-se dizer que os fenômenos demográficos se situam na interface do biológico e do social. Encontra-se sobretudo em jogo todo o campo da saúde e do exercício das funções reprodutivas (da gestão e produção do corpo). A análise sobre esta questão deve ser conduzida simultaneamente no nível biomédico e no nível das práticas sociais - com tudo que comportam em termos de representações, de saber coletivo, de objetivos sociais. Além da constatação da existência de algumas inter-relações entre as práticas de natalidade e estratégias de busca de segurança, este campo de investigação permanece pouco desenvolvido. Para tratar esse problema com mais rigor, é fundamental uma colaboração entre as ciências humanas (incluindo a demografia) e as disciplinas biomédicas. Estudos interdisciplinares, conduzidos no meio urbano de Maradi, mostraram como pode ser frutífera esta colaboração e de que maneira pode afastar falsas evidências. Isto é particularmente verdade no relativo a correlações mecânicas que poderiam ser feitas entre as condições de vida material de uma população e suas condições de saúde (Raynaut, 1989). Ao contrário, tem sido possível demonstrar que as relações sociais (especialmente aquelas que se organizam na forma de redes de solidariedade) e as representações coletivas (na medida em que se expressam em práticas concretas) exercem uma influência determinante no estado geral de saúde das crianças e, portanto, sobre as condições de reprodução biológica dos grupos a que pertencem e constituem a progenitura.

Doença e mortalidade estão contidas numa lógica que está longe de ser exclusivamente médica. Há múltiplas evidências no sentido de mostrar que os fenômenos de saúde são inseparáveis - ao mesmo tempo como causa e efeito - do conjunto da vida social e material de um grupo. Basta pensar no impacto da doença no funcionamento de sistemas de cultivo que se baseiam quase que exclusivamente na força do trabalho humano: uma deficiência física, a indisponibilidade durante um período crucial do calendário agrícola e o conjunto da produção anual se compromete. Meillassoux insiste corretamente sobre o papel que o tamanho demográfico da unidade de produção doméstica desempenha na segurança contra as incertezas doença (Meillassoux, 1982: 69). Seria necessário, de fato, ampliar a análise e considerar as estruturas de cooperação que unem as células familiares entre elas e se mobilizam no caso de acidente. Justamente é neste ponto que a atual fragmentação das estruturas familiares e o enfraquecimento da solidariedade coletiva tornam cada vez mais crucial a manutenção da saúde, única garantia da integridade da força de trabalho disponível. Não é de se admirar, nestas condições, que a demanda de serviços de saúde seja a que é mais enfaticamente expressa pelas populações rurais. Proteger os vivos e assegurar a fecundidade das mulheres são formas de se multiplicar os braços, objetivo que está, há séculos, no centro das estratégias de sobrevivência das comunidades camponesas.

Mesmo se hoje, como acabamos de ver, tornase mais importante controlar a terra e possuir ferramentas do que acumular força de trabalho manual, esta ainda se constitui num elemento central para a agricultura local. Além disto, ter um grande número de filhos é a garantia mais segura de uma velhice tranquila. A saída do vilarejo de alguns membros da unidade familiar se traduz em uma diversificação na gestão do capital humano, o que permite, muitas vezes, a expansão das fontes dos recursos familiares: muitas famílias vivem graças aos intercâmbios entre aqueles que partiram para a cidade e aqueles que ficaram no campo. 
$\mathrm{O}$ fato de que a fecundidade e a fertilidade de uma família sejam objeto de uma forte valorização social pode nos levar a considerar estes elementos coletivos como a expressão ideológica de estratégias materiais voltadas para a busca de segurança. Isto, no entanto, seria perder de vista que estes valores estão também enraizados em uma visão global do universo e das forças que os animam: o número de filhos é a prova da existência de uma "energia vital", da "força" de uma pessoa (da mesma forma que a abundância de suas colheitas). Estas normas sociais se justificam em si mesmas e continuam a inspirar os comportamentos individuais, mesmo quando elas se mostram inadequadas diante do surgimento de limitações novas: neste caso, o rápido crescimento populacional, a rarefação do espaço e o conjunto das consequências que daí decorrem. É certamente verdadeiro que o desmantelamento de uma sociedade de linhagem e do sistema de representação religiosa que lhe é subjacente, assim como a emergência de uma nova visão do lugar do indivíduo na sociedade e no mundo (ver mais adiante) favorece a evolução das atitudes em relação à fecundidade no sentido de levar cada vez mais em conta as necessidades materiais. Mas isto virá como resultado de um longo processo de ajustamento ${ }^{23}$.

Se as mudanças demográficas nas comunidades camponesas de Maradi refletem suas estratégias internas, elas também mostram o impacto que a assistência médica vinda de fora provocou. Desde o início do período colonial no Níger, como em outras regiões do oeste africano, vêm sendo realizadas campanhas em larga escala contra muitas doenças endêmicas importantes e que conduziram, por exemplo, à erradicação da varíola. A aceleração do crescimento populacional deve-se, em grande parte, aos efeitos positivos da redução da taxa de mortalidade, especialmente a infantil. Entretanto, há ainda muito trabalho a ser feito no campo do saneamento, como pode ser constatado através das enormes disparidades entre as infraestruturas urbana e rural (Raynaut, 1987), através dos centros de atendimento médico e pelos indicadores oficiais de saúde (Frère et al., 1987; Lebras, 1986). A subnutrição infantil, a diarreia e a malária continuam a dizimar populações rurais. Mais de um quarto das crianças nascidas vivas morre antes de atingir cinco anos. As altas taxas de natalidade têm como consequência um tão grande aumento populacional que o sistema de produção agrícola não tem capacidade para responder à demanda (nem em termos de produção, nem em termos de equilíbrio ambiental ${ }^{24}$. Quando se examina a reprodução demográfica das sociedades locais sob o ponto de vista de sua lógica interna, percebe-se que ela depende da articulação estreita de três parâmetros: morbidade e mortalidade humanas, funcionamento dos sistemas agrícolas e estratégias natalistas das unidades familiares. É impossível considerar apenas um destes parâmetros sem levar em conta os outros dois.

Sobre este aspecto, talvez mais do que sobre outros, um projeto de desenvolvimento, como o de Maradi, é apenas parte de um programa muito maior, tanto em amplitude, quanto em duração. $\mathrm{Na}$ verdade, aqui como em outros lugares, as relações entre a produção agrícola e a reprodução demográfica não são levadas em consideração. No máximo, os limites e as exigências criadas por um rápido aumento populacional são ocasionalmente observados, mas isto não parece conduzir a nenhuma opção planejada coerente na área do desenvolvimento agrícola e da saúde. As migrações têm sido frequentemente interpretadas como meras manifestações de comportamentos individuais (busca de novos horizontes), em vez de serem vistas como uma resposta coletiva à crise da sociedade rural: não é nem considerado o fato que as ações de desenvolvimento sejam sucetíveis de inibir ou provocar estes movi- 
mentos ${ }^{25}$. Neste caso, mais do que a "resistência" das sociedades camponesas à mudança, é a inércia específica das instituições promotoras do desenvolvimento (especialmente as barreiras que se erguem entre os diferentes territórios burocráticos), assim como sua insuficiência teórica para se representar a realidade, que devem ser questionadas.

\section{A reprodução social e as transformações numa sociedade camponesa}

A lógica ou as muitas lógicas da reprodução social cobrem um vasto campo de análise, mas que serão aqui apenas brevemente consideradas. Lembremos simplesmente que através de manifestações particulares que assumem as formas específicas das relações sociais (por exemplo, senhor/escravo, chefe político/sujeito, patrão/cliente, chefe de família/dependente, homem/mulher), predomina um princípio na sociedade Haussa: o da integração dos indivíduos numa cadeia hierárquica de relações interindividuais. Em alguns casos, essa cadeia era a manifestação visível de estruturas estáveis, tais como a linhagem familiar ou uma unidade territorial (um vilarejo ou um pequeno domínio). Em outros, eles correspondiam a redes menores e mais limitadas, especialmente aquelas construídas em bases mais individuais e interdependentes, como, por exemplo, entre patrão e cliente (Grégoire, 1986). Nesse contexto social, o destino do indivíduo se inscrevia estritamente no interior dos campos em que havia sido socializado e ao qual pertencia. A estrutura de descendência patrilinear, reforçada pela concepção sobre a herança, se constituíam no modelo predominante no sistema de relações sociais $^{26}$. A organização da produção, a gestão e a circulação dos bens refletem a lógica da reprodução dessas redes e estruturas. Em termos concretos, isto significou, por exemplo, que as relações de aliança puderam se expressar e se renovar periodicamente através do trabalho de homens e mulheres jovens, nos campos familiares coletivos; do trabalho dos indivíduos nas terras de seus chefes, de clientes nas terras de patrões Não se trata de uma reconstrução teórica a posteriori, mas de uma realidade vivida e colocada ao serviço de estratégias deliberadas: assim, a acumulação de terras e a contratação de trabalhadores praticadas por alguns comerciantes ricos de Maradi buscava reforçar sua posição social e política tanto quanto a obtenção de renda (que pode até ser algo incerto). Foi mostrado, em outros trabalhos, que a redistribuição de bens e de dinheiro, especialmente via presentes, é o principal canal para a demonstração e a manutenção de estruturas sociais (Nicolas, 1975; Raynaut, 1973).

Ao restringir a discussão a generalizações, tende-se a simplificá-la muito, beirando-se o truísmo. Entretanto, é importante enfatizar a coerência existente entre o sistema das relações sociais, das representações e das práticas técnicas. Em resumo, pode-se dizer que, em relação à agricultura, a visão de mundo predominante era a de que o homem apenas usufruía da terra que ele cultivava. Embora tivesse um reduzido acesso aos recursos do meio ambiente, sua individualidade como produtor tinha que estar integrada na comunidade - o único corpo social permitido para estabelecer alianças coletivas com as divindades. Esta concepção era perfeitamente compatível com métodos de cultivo que favoreciam o uso temporário do solo no lugar de sua ocupação permanente e dava prioridade à gestão da força de trabalho e não ao controle da terra.

Nesse contexto, o processo de mudança também se manifesta como uma subversão radical de uma lógica bem estruturada. Essas mudanças assumiram uma dupla dimensão - uma objetiva e outra idealizada. 
As mudanças objetivas provocaram a fragmentação das estruturas sociais anteriores - especialmente aquelas baseadas na linhagem -, o que proporcionou uma individualização gradual das relações entre a pessoas e seu meio material e social. Embora não se possa subestimar os efeitos de estruturas políticas antigas, parece que a manifestação mais óbvia dessa ruptura repousa na divisão das unidades domésticas de produção. Cada vez mais, seu tamanho se reduz ao tamanho da família nuclear $^{27}$. É verdade que as velhas estruturas estão longe de estarem mortas e que os laços da família extensa continuam a exigir certas obrigações; mas se estas estruturas sobrevivem é porque representam mais a expressão de solidariedade entre os indivíduos do que um quadro de referência para uma identidade coletiva, ou um lugar onde uma pessoa deva cumprir seu destino.

As evoluções do sistema de representação se manifestam mais claramente no colapso das religiões ancestrais que serviam de base ideológica para as estruturas patrilineares e instituíam a existência de uma herança comum. De suas cinzas nasceu um novo sistema que permite ao indivíduo ver-se numa relação autônoma com o mundo. Essa nova visão do universo foi tomada de empréstimo do Islam, especialmente a ideia de uma relação pessoal com um Deus único e universal. No entanto, continuam ainda a se nutrir da antiga cultura pré-islâmica e reinterpretam certos conceitos como "sorte", "força" e "destino". Há um exemplo concreto dessa evolução no aparecimento do modelo social do Alhaji (peregrino), que, pelas suas qualidades empreendedoras e pela sua "força" e sua "sorte", conseguiu adquirir dinheiro suficiente para empreender uma peregrinação a Meca. Essa forma de consagração substituiu Sarkin Noma (Mestre da lavoura), que perdeu sua posição em função de uma ostentatória distribuição de grandes quantidades de grãos e de riqueza, acumulados sob o argumento da coesão das linhagens. Isso demonstra duas noções radicalmente opostas de "destino".

Assim, há uma verdadeira redefinição dos princípios básicos sobre os quais a nova ordem social está sendo construída. Se este fato for ignorado, perde-se a oportunidade de analisar um dos aspectos mais fundamentais dessas mudanças. Mais especificamente, corre-se o risco de minimizar o que representa, de fato, o traço mais marcante da transformação que presentemente afeta a sociedade camponesa Haussa, ou seja, um processo de diferenciação econômica, baseado não mais em antigas hierarquias sociais que se tornaram inoperantes, mas no controle de fatores materiais - terra, implementos técnicos - cujo papel, como foi visto anteriormente, é predominante no processo de produção. Um crescente abismo separa agora duas categorias extremas de agricultores. Num extremo, encontra-se uma minoria que se beneficiou de alguma terra e de fontes de mercado não diretamente ligadas à agricultura e que pôde assim modernizar suas técnicas e manter os níveis de produtividade que os protegem das consequências da insegurança climática. No extremo oposto encontram-se muitos que estão lutando meramente para sobreviver num pedaço mínimo de terra, fazendo um esforço tremendo para maximizar a produtividade de seu trabalho, sem que com isto consigam reinvestir, o que poderia ajudá-los a manter o potencial dos recursos por eles explorados ${ }^{28}$. Frente às atuais condições, sua posição só pode piorar com o passar dos anos. Esses dois grupos não somente coexistem, como estão vinculados por uma relação de troca desigual que reforça a posição dos agricultores melhores posicionados e enfatiza a vulnerabilidade dos mais pobres. Estes vendem sua força de trabalho e posteriormente sua terra aos mais ricos. Entre esses dois extremos há posições intermediárias, mas estas estão sujeitas aos 
movimentos que poderão conduzi-las na direção de um polo ou de outro. Neste sentido, as secas das últimas décadas funcionaram como uma espécie de mecanismo de seleção. Alguns agricultores sucumbiram ao choque e outros aproveitaram-se da falência dos primeiros. A migração que se observa entre as regiões rurais e as cidades (na Nigéria ou no Níger) é, portanto, o resultado das mudanças por que passa a sociedade rural.

Aqui não podemos deixar de ser esquemáticos. Entretanto, afirmamos o suficiente para mostrar a complexidade das mudanças que estão atualmente ocorrendo e a dimensão social da crise agrária que se manifesta como uma alteração da lógica das relações sociais. Face a esta realidade, a ação de um Projeto de Desenvolvimento tal como o de Maradi tem pouca influência. Menos ainda porque a dimensão social das intervenções técnicas foi completamente ignorada. Até recentemente, a visão que se tinha da sociedade camponesa era extremamente fragmentada e muito estereotipada, pois baseava-se no nível de exploração agrícola e a imagem que se tinha era a do "agricultor médio"29.

Na verdade, as possibilidades de uma manipulação deliberada e planejada da dinâmica das relações sociais são, no mínimo, ilusórias. Não obstante, a questão das dimensões sociais de uma ação de desenvolvimento não pode ser descartada. Se os processos de diferenciação socioeconômicos que transformam atualmente a sociedade camponesa Haussa forem ignorados, ou não forem levados em conta, corre-se o risco de agravá-los sensivelmente. É claro que neste sentido uma estratégia extensionista que se baseie no suporte aos indivíduos "dinâmicos" - em outras palavras, àqueles que já se encontram em situação melhor - pode vir a agravar as disparidades já existentes. Mais do que isso, se não nos dermos conta das consequências da individualização das relações de produção e do incremento da competição entre os agricultores, perde-se qualquer possibilidade de contribuir para a solução dos problemas que se colocam na comunidade local. Experiências recentes realizadas nos últimos anos em Maradi mostraram que tentativas de desenvolver a cooperação entre vilarejos, em vez de se instigar a competitividade, têm muitas possibilidades de serem bem-sucedidas e poderão ajudar significativamente aos agricultores como um todo ${ }^{30}$. Naturalmente que isto não significa que todas as contradições internas da sociedade camponesa desaparecerão, mas a intervenção externa pode, algumas vezes, criar condições apropriadas para clarificar a situação e proporcionar algum tipo de negociação entre as categorias sociais com interesses divergentes, em lugar de se contentar em satisfazer as necessidades daqueles que ocupam os melhores lugares ou que podem ter livre acesso ao mercado.

Em resumo, a intervenção desenvolvimentista tal como foi aqui descrita não tem uma influência motora, tanto no campo social como no material. Ela é apenas uma parcela de um processo de transformação mais global. Entretanto, sua influência não é nula: ela pode, levando em consideração a diversidade de interesses com que se defronta, reforçar, intencionalmente ou não, as mudanças que já se iniciaram, ou tentar amenizar essas mudanças.

\section{As lógicas externas}

Em resposta à questão colocada anteriormente sob um plano mais global, constata-se que o movimento geral de transfonnações por que passa a sociedade rural Haoussa tem sua origem numa combinação de choques e de pressões exercidos por fatores externos. É lógico que a natureza das mudanças e a maneira como elas se apresentam refletem a 
dinâmica intrínseca das diferentes lógicas (social, material e demográfica) e a maneira através da qual elas reciprocamente se vinculam. No entanto, as contradições internas têm revelado o aprofundamento de suas fraturas como resultado dessas pressões externas. Com exceção dos acidentes climáticos, essas forças externas não são o resultado de eventos aleatórios, mas de lógicas históricas de grande dimensão. Uma delas se relaciona à constituição do Estado-Nação e de seu aparato de poder. Numa escala maior, tal movimento pressupõe o enfraquecimento da coesão das comunidades locais. Outra tem por base o funcionamento da economia de mercado. Esta última é a que será aqui enfatizada, mesmo que rapidamente, pois esta questão tem sido bastante analisada nos estudos sobre as sociedades sahelo-sudanesas.

Será retomada aqui uma das primeiras observações realizadas sobre a sociedade Haussa (Raynaut, 1977), a de que a moeda invadiu praticamente todas as esferas do sistema econômico: na produção (terra e trabalho são mercadorias em potencial); no consumo (a alimentação cotidiana passa hoje pelo mercado - Raynaut, 1978); nas trocas (mesmo os presentes são hoje dados em moeda). A sociedade camponesa necessita hoje de dinheiro para se reproduzir material e socialmente. Como foi visto, esta exigência é agora ainda mais imperativa na medida em que os reajustes nos sistemas de produção agrícola se sustentam cada vez mais na compra de fatores de produção externos.

Nesse contexto, fica claro que os fluxos monetários que vinculam as comunidades rurais à economia nacional têm influência marcante. Considere-se, por exemplo, o sistema excessivamente oneroso de taxação de impostos que já existe há muitos $\operatorname{anos}^{31}$. Mais importante ainda são os mecanismos de preços e a relação em termos de troca que se estabelece entre a produção camponesa e os produtos adquiridos no mercado. A estagnação dos preços agrícolas que ocorreu entre 1950 e 1975 , tanto quanto a espiral ascendente da última década, são também fenômenos essenciais para a compreensão dos choques e ajustes rápidos que a sociedade rural e seus sistemas produtivos vêm atravessando (Raynaut, 1987b). Assim, direta ou indiretamente, a lógica de mercado impõe suas regras ao mundo rural como um todo, tanto no que diz respeito ao seu equilíbrio global como sob o ponto de vista dos comportamentos individuais. As buscas de lucro e rentabilidade são atualmente imperativos aos quais os camponeses não podem escapar, ao mesmo tempo que procuram conciliá-las com outras formas de troca, em particular o sistema de doações, que ainda é um dado essencial no funcionamento das instituições (Raynaut, 1973).

Essa questão tem sido exaustivamente analisada. Aqui será apenas assinalado que poucas operações de desenvolvimento são capazes de levar contribuições duradouras às comunidades camponesas e ao seu ambiente econômico global. É muito difícil controlar os preços dos produtos agrícolas numa época em que até os produtos alimentares têm uma dimensão internacional (Egg, 1987), e a mesma afirmação é verdadeira para a maioria dos produtos de consumo. Os fatores da produção recebem subsídios ocasionais (este foi o caso de Maradi entre 1976 e 1982), mas esses nunca podem se manter diante do aumento na demanda e em função de seu alto custo. Por outro lado, a ideologia "liberal", predominante nas instituições de financiamento internacional, recusa-se a transformar os camponeses em "assistidos" e defende uma política dos preços "reais". O exemplo do Projeto de Desenvolvimento de Maradi, entretanto, contradiz esta teoria: de fato, o período em que o Projeto distribuiu, com sucesso, equipamentos técnicos coincide com a época em que a balança comercial entre a produção agrícola 
e o comércio se apresentava, em termos nacionais, favorável. (Raynaut et al., 1988). A estratégia de desenvolvimento proposta pelos peritos se baseia num grande paradoxo: ao acelerar a inserção da economia camponesa no sistema de mercado, ela torna-se um instrumento de mudanças que já haviam se iniciado no período colonial, mas não fornece aos agricultores os meios para enfrentar sua vulnerabilidade em relação às forças de mercado que os tornam cada vez mais dependentes. A recusa da interferência na regulação dos preços deixa os agricultores desprotegidos e os coloca diante de mecanismos sobre os quais não têm nenhum controle e que, geralmente, agem contra eles.

\section{Um projeto, sua lógica e sua história}

O que se questiona no caso do Projeto de Desenvolvimento de Maradi é a maneira pela qual a intervenção foi concebida porque, como foi visto, ela se distancia da realidade dos problemas a que deveria responder. Qual é a razão para essa miopia? É muito fácil reduzir os aspectos funcionais de um programa de desenvolvimento ao seu objetivo oficial básico, como, por exemplo, o lado técnico-econômico. Entretanto, esquece-se que esse programa fará parte da história, tanto de sua própria como daquela mais antiga e mais ampla, que envolve relações entre as comunidades camponesas e os aparelhos de desenvolvimento. Somente se esta história for levada em consideração é que será possível verificar as lógicas institucional e política latentes, às quais a intervenção desenvolvimentista tem que se ajustar. Não será aqui traçada a história passada do desenvolvimento rural da região de Maradi e nem será fornecida uma descrição detalhada da criação do Projeto Maradi. Colocaremos apenas algumas indicações que permitem apontar e identificar as principais questões.
Em primeiro lugar, é importante recordar que a popularização dos aspectos técnicos não se iniciou com o Projeto. Durante o período colonial, ocorreram muitas intervenções agrícolas, cujas iniciativas partiram não somente dos serviços administrativos, com a criação das Sociétés Mutuelles de Développement Rural (S.M.D.R.), como também do Sudan Interior Mission, uma organização confessional nigeriana muito poderosa e que organizou, próximo a Maradi, algumas escolas para treinamento agrícola. Após a independência, esse trabalho teve prosseguimento através da Union Nigérienne de Crédit Coopératif (U.N.C.C.) e pelo departamento de agricultura local. Todos esses esforços objetivamente somente um sucesso relativo principalmente porque, naquela época, havia ainda muita terra disponível para que os agricultores pudessem sentir a necessidade de mudanças técnicas. Mais do que isto, as condições econômicas globais (os níveis de impostos, os preços agrícolas) desencorajavam o investimento dos camponeses (Raynaut, 1975). Entretanto, novas técnicas foram se infiltrando progressivamente na sociedade rural e uma pequena minoria, que já dispunha de melhores condições, começou a comprar implementos de tração animal ${ }^{32}$. Neste sentido, não é por acaso que a área onde a extensão rural tem obtido maior sucesso coincida com a área onde se concentraram esforços já por mais de meio século.

No entanto, para compreender os problemas atuais, outras pistas essenciais devem ser procuradas em outro lugar, ou seja, nas mudanças radicais da política de desenvolvimento rural no Níger. A criação do Projeto Maradi foi a expressão dessas mudanças. Desde a Independência até a época do Projeto, a ênfase absoluta tem sido dada ao desenvolvimento de recursos humanos, através de uma política ambiciosa de animação rural, que incluía a criação de cooperativas e campanhas de alfabetiza- 
ção. Durante muito tempo, o conteúdo ideológico dessas iniciativas extrapolou seus aspectos práticos e concretos. Por exemplo, as cooperativas eram vistas mais como uma escola para a democracia - através do controle da comercialização do amendoim - do que como um meio para o desenvolvimento agrícola. Essa dimensão política foi tão real que a estrutura do movimento de animação rural, com seus comitês por vilarejo, era frequentemente vista por observadores locais como o "Partido do Presidente Diori", que fez dupla com o único partido político oficial (P.P.N.-R.D.A.), controlado pelo segundo homem mais forte do país, Boubou Hama (Raynaut, 1990). Em 1972, entretanto, respostas técnicas foram necessárias para ajudar a solucionar problemas de uma grave crise na economia rural. Estimulados pela perspectiva de financiamento pelo Banco Mundial, pessoas do local e do distrito uniram seus esforços e elaboraram um "Pré-Projeto de Desesenvolvimento" (Commissariat General au Développement, 1972). Nesse estudo, foi tentada uma integração entre os eixos maiores da intervenção - produção agrícola-pastoril e meio ambiente - numa visão global de planejamento regional. O mais original desse documento é o fato de levar em consideração o uso da terra (especialmente em relação à densidade populacional e à competição pela terra entre a lavoura e a criação de animais). Esses problemas foram identificados através de um processo abrangente de consulta à população rural, com a ajuda das cooperativas e das estruturas políticas tradicionais. No entanto, nenhum desses objetivos preliminares foi incorporado pelo Projeto de Desenvolvimento, elaborado quatro anos mais tarde. A razão principal foi a oposição intransigente do Banco Mundial a qualquer esquema que pudesse impedir a aplicação de seus próprios critérios de rentabilidade financeira. Grupos de peritos sucessivamente enviados pelo Banco rejeitaram a ideia de que a intervenção devesse abranger a totalidade da região departamental. Insistiam no fato de que o Projeto deveria se limitar às áreas mais meridionais, onde o índice de chuvas era menos desfavorável e para onde um acordo de empréstimo poderia obter maior rentabilidade financeira. O Banco foi também relutante em concordar com qualquer esquema de gestão da terra, já que esta deveria ser realizada pelas comunidades locais. Para melhorar a produtividade das culturas, preferiram concentrar seus esforços na popularização de opções técnicas que já haviam sido "experimentadas e testadas" em laboratórios de pesquisa ${ }^{33}$.

As autoridades nigerianas, especialmente a Comissão para o Desenvolvimento, se opuseram a essas exigências e a disputa continuou até 1974, ano marcado por uma seca devastadora e também por um golpe de Estado, no qual os militares tomaram o poder. O novo regime era muito mais aquiescente às ideias do Banco Mundial que, naquela época, também acenava com previsões quantitativas na melhoria da produção e, mais importante, foi contra a estratégia de desenvolvimento que havia colocado muita ênfase no programa de mobilização rural considerado suspeito também pelos novos donos do poder, em virtude de suas conotações "políticas". Foi assim que, em 1976, o Projeto Maradi tomou corpo, alinhando-se, em grande parte, às recomendações do Banco Mundial. Isto representou o triunfo de uma abordagem técnica sobre um processo integrado, que já havia adquirido uma dinâmica coletiva e que contava com uma liderança camponesa que havia organizado seus pontos de contato na comunidade rural.

Entretanto, daquele momento em diante, a maioria dos recursos destinados ao desenvolvimento rural na região foi monopolizado pela estrutura recentemente instalada. Esta estrutura, pouco a pouco, vai se transformando em uma burocracia 
que passa a consagrar o essencial de seus esforços a sua própria manutenção. Com o passar dos anos, os abusos e a corrupção tornaram-se generalizados. Esta deterioração sofreu uma interrupção em 1984, por iniciativa de certas forças políticas e do próprio agente financiador que, nesse meio tempo, havia mudado sua concepção de desenvolvimento e estava agora convertido às virtudes de um "desenvolvimento com base comunitária". As estruturas administrativas foram consideravelmente reduzidas e foram despedidos centenas de funcionários. Ao mesmo tempo, esforços estavam sendo feitos para reorientar a ação desenvolvimentista, consoante com uma abordagem mais flexível, mais colada às realidades regionais. Apesar dessa reorientação, o peso da estrutura interna do Projeto se mostrou muito importante. Mas, após vários anos reinando sozinho, a hostilidade que se concentrava ao seu redor era enorme para que a experiência pudesse ser bem-sucedida e foi então fechado em 1988.

Dessa história, bastante resumida, uma conclusão pode ser tirada: o Projeto Maradi não foi o agente de um simples procedimento técnico de desenvolvimento, totalmente separado da realidade social; ele foi o instrumento de estratégias que se justificavam no progresso da agricultura, mas que, de fato, estavam envolvidas com outros interesses. Para o poder nacional, o problema era consolidar o controle sobre as populações locais. Quanto à burocracia local, seu objetivo era tirar vantagem do considerável aporte de fundos. Por último, o Banco Mundial tentou estreitar sua presença num país particularmente debilitado, enquanto permanecia fiel aos seus princípios como instituição financeira.

Do lado das comunidades camponesas, elas não se tornaram insensíveis à reviravolta do discurso em relação ao desenvolvimento e nem ao abandono da abordagem "participativa", na qual alguns de seus membros haviam se envolvido pessoalmente. Tanto quanto o abuso cometido no período anterior ${ }^{34}$, a mudança veio alimentar suas dúvidas em relação a um aparelho administrativo que lhes parecia uma estrutura de poder movida muito mais pela sua própria lógica do que como um parceiro com o qual se pudesse investir uma confiança duradoura. Não se deve esquecer que, embora projetos e equipes de trabalho se sucedam ano após ano, pensando a cada vez que estão partindo do zero, os camponeses conservam na memória todas as tentativas abortadas e as promessas não cumpridas!

Não se trata aqui de fazer nenhum julgamento de valor sobre esses acontecimentos. É assim a história do desenvolvimento, em Maradi ou em qualquer outro lugar. Ela é sempre resultante da relação de forças que se expressa pelo enfrentamento entre estratégias externas ao mundo camponês e as dinâmicas internas que atravessam este último. Portanto, se o processo de desenvolvimento continuar sendo representado como um simples embate entre iniciativas de desenvolvimento protagonizadas por agentes acéticos do "progresso" e as sociedades rurais como sendo mais ou menos prisioneiras do peso da "tradição", sempre se produzirá uma reconstrução totalmente distorcida da realidade.

\section{Conclusão}

Partindo da análise de um exemplo concreto, este artigo tentou mostrar o valor da aplicação de uma abordagem holística à análise do desenvolvimento. O modelo analítico proposto é certamente bastante simplista, mas este é o preço a ser pago para que se possa trazer alguma ordem à complexidade e ir além do conceito básico de que "tudo se junta". Por ora, trata-se apenas de um momento, de uma reflexão, cujo aprofundamento é indispensável, 
especialmente no nível teórico. Isto é particularmente necessário no que diz respeito à natureza das interconexões internas sobre as quais o sistema lógico se baseia, assim como a natureza das relações que unem as diferentes lógicas. $\mathrm{O}$ conceito de compatibilidade foi mencionado e deve ser melhor desenvolvido, junto com os conceitos de ruptura e de crise. Entretanto, para evitar que esta reflexão se faça sob uma base dogmática, é necessário buscar dados em um grande número de situações concretas. Isto só pode ser obtido pela integração de dados obtidos das diferentes disciplinas sociais, naturais e ciências da vida. Nesta perspectiva, o modelo de análise aqui proposto pode ser utilizado como um instrumento de pesquisa, como uma estrutura básica para uma abordagem interdisciplinar. Seu caráter geral implica também uma certa perda de detalhes em cada disciplina. $\mathrm{O}$ diagrama não pretende explicar a realidade em termos abrangentes, mas fornecer um resumo topológico, através do qual os problemas possam ser formulados. Tendo isto como base, áreas de convergência temática podem ser identificadas, resultando numa colaboração para a pesquisa de campo. Desta forma, cada disciplina científica pode aplicar seus próprios conceitos e métodos, com pleno conhecimento de onde e como esses se articulam às outras disciplinas, dentro de um processo geral de compreensão de uma dinâmica mais abrangente.

A aplicação de tal procedimento numa situação de desenvolvimento permite, como aqui tentamos demonstrar, descartar a falsa premissa de que é

\section{Notas}

1. Sobre essas primeiras análises sobre a seca, ver especialmente: Comité Information Sahel, 1974; Copans et al., 1975; Dalby et al., 1977. a própria intervenção desenvolvimentista que se constitui na força motriz da mudança. Ao contrário, a intervenção é reconduzida ao seu devido lugar frequentemente muito pequeno, mas não negligenciável -, no curso de uma evolução que a incorpora e a suplanta. Embora benéfica, deve-se também ter claro o perigo potencial que uma abordagem global pode esconder: o de fazer crer que o acesso a uma visão de conjunto permitiria uma ação mais sistemática, mais eficaz e que seria possível, assim, planificar a mudança global sem passar por conflitos e crises. O risco aqui é o de uma ilusão cientificista, ou seja, a crença de que é possível adotar uma posição desprendida em relação à realidade que daria uma imagem imparcial e racionalizada das coisas. Tal concepção sobre o conhecimento e sua aplicação estão condenadas ao insucesso, porque não levam em consideração o fato de que a intervenção externa, seja ela científica ou não, torna-se inevitavelmente um elemento de uma dinâmica social e política. Face a uma dada situação, em geral há soluções múltiplas que podem ser contempladas. Escolhas finais nunca podem ser mais do que a expressão de um equilíbrio de forças que se estabelecem entre os diferentes atores. O conhecimento obtido através da análise científica pode ter somente um papel positivo: o de tornar transparentes as questões vitais e, assim, tornar-se ele próprio um componente da dinâmica social. Logicamente, a questão seguinte é o destino das informações e de que forma e em que condições os dados de pesquisa devem ser divulgados. Mas isto é uma outra história.

2. O rio Níger tem baixado seu nível de maneira catastrófica nos últimos quinze anos, um fenômeno característico da situação pluviométrica em toda a sua bacia (Billon, 1984-85).

3. P. Richards (1983) fornece uma análise crítica interessante sobre uma aplicação simplista das teorias da dominação. 
4. Em relação à agricultura francesa, ver particularmente as análises apresentadas em Études Rurales, 1978.

5. Godelier desenvolveu as implicações teóricas dessa noção "ideacional" (1984). Aqui será retida apenas a sua formulação mais direta e mais simples.

6. Ver especialmente a análise pelo Banco Mundial sobre o problema de desertificação da região africana do Sahel-Sudão. Essa análise enfatiza a noção da "tolerância populacional" pelo ecossistema (1985).

7. Há exemplos desse movimento dual fora da região sahelo-sudanesa. No Quênia, a recente intervenção para modificar práticas econômicas e técnicas relacionadas ao uso da madeira acabou em conflito com os papéis simbólicos e religiosos de árvores e aos interditos às mulheres relacionados a esta questão (Bradley, 1987). Isto mostra que, nessa área, antigos sistemas de representação continuam ainda bastante influentes. Não obstante, desde o início do século, novos elementos técnicos (milho, enxada de metal) se inseriram nos sistemas de produção camponeses, modificando profundamente as bases sociais de seu funcionamento (Bernard, 1972).

8. Há muitos exemplos dessas discrepâncias. No campo da saúde, progressos em relação aos conceitos sobre alimento e higiene (introduzidos pelas escolas, centros de saúde e rádio) contrastam com a impossibilidade de tornar esses conceitos uma realidade concreta, em função das condições atuais de vida. Por outro lado, regras baseadas nos costumes, relacionadas ao uso de plantas não cultivadas, estão sempre em oposição a limites materiais que surgem devido à pressão sobre a terra e podem se tornar um fator de contribuição à erosão do meio ambiente natural do Sahel.

9. A organização interna dos sistemas de representação é um estudo em si mesmo, como pode ser visto nos trabalhos de antropologia estrutural (Lévi-Strauss em particular). Esta questão é bastante relevante quando uma cultura busca unificar suas representações sobre o universo, fazendo com que as diferentes áreas da realidade correspondam reciprocamente, dentro de um mesmo quadro de referência. Ocasionalmente, como resultado de uma diversificação social e cultural, pode haver uma falta de coerência, isto é, lacunas entre os sistemas específicos de representação.

10. Morin (1984) desenvolveu essas noções de reprodução, evolução e crise.

11. Em relação às noções de ordem e desordem no campo da organização social, ver as análises de Morin $(1984,1977)$.
12. Esse termo é emprestado de Monod (1970). Ele o usa no contexto da biologia para indicar o objetivo comum que dirige a articulação de processos dinâmicos, em que a célula viva é o contexto. Aqui extrapolou-se para o campo do social com o sentido de introduzir a ideia de uma orientação na cadeia de relações entre os elementos de um sistema social, sem ter que denominá-los pela noção mecânica e restritiva de "função".

13. Neste contexto, leia o que pensam Crozier e Friedberg sobre o agente e o sistema (1977). Num estudo sobre uma pequena comunidade Haussa, foram analisadas as tensões entre estruturas coletivas e estratégias individuais (Raynaut, 1973).

14. Dois grupos de disciplinas estão ansiosos para aplicar uma abordagem global à análise material. Na França, as ciências sociais adotaram uma abordagem teórica fundamental e a revista "Techniques et Cultures" tem divulgado as tendências atuais sobre o tema. Disciplinas técnicas, tais como a agronomia e a agroecologia, têm buscado um objetivo mais pragmático, motivando-se e dirigindo-se ao desenvolvimento (ver, em particular, "Cahiers de la Recherche-Développement"). Um volume do "Cahiers de l'ORSTOM", que trata da implementação de arados na África tropical, contém muitas contribuições que permitem definir melhor as lógicas técnicas no campo da agricultura, especialmente as contribuições de Bernadet (1984), Marchal (1984) e Sigaut (1984).

15. Alguns elementos relacionados a essa linha de pensamento são tratados brevemente por Gregory \& Piché, 1985.

16. A noção de "embricamento" da economia nas outras esferas da vida social foi desenvolvida por Polanyi \& Arensberg (1957), e posteriormente reexaminada e aprimorada por Godelier no prefácio da edição francesa de seu livro (1975).

17. É claramente artificial separar a política da economia, já que a construção e a manutenção de um sistema de poder devem, necessariamente, envolver processos de troca e de acumulação de bens e de riqueza. Novamente aqui, entretanto, não se está definindo esferas de práticas sociais que são mutuamente independentes, mas identificando áreas de articulação nas quais itens relevantes à análise podem ser reconhecidos.

18. Teorias sobre a dominação são geralmente muito dogmáticas e isto tem conduzido a um debate estéril sobre a teoria de um "campesinato não subjugado", introduzido por Hyden 
(1980). Só pelo fato de não se encontrar subserviência por parte da economia camponesa africana aos princípios das trocas de mercado, não significa que não haja uma total dependência. Meillassoux (1975) mostra claramente que o grau de permanência num setor de economia doméstica pode ser uma condição para a exploração da força de trabalho dos camponeses sahelo-sudaneses.

19. Para uma análise crítica desse problema, ver especialmente Boiral et al., 1985.

20. O feito de políticas de desenvolvimento sobre a saúde de populações como um todo tem sido objeto de preocupação da WHO só recentemente. Ver os pronunciamentos do Diretor Geral na “Assembleia Mundial da Saúde”, em maio de 1989.

21. Este projeto financiado pelo Banco Mundial durante nove anos - com valor médio de um bilhão C.F.A. de francos anuais - foi estabelecido em julho de 1976. Tornou-se operacional em 1977. O objetivo principal era incrementar a produtividade de culturas pluviais. Para atingir este objetivo, a intervenção foi organizada em quatro temas técnicos: o uso de sementes selecionadas; tratamento de sementes; semeadura densa e uso de quantidades recomendadas de fertilizantes. Acrescentando-se a isto, havia o que se denominava objetivos secundários, tais como o preparo do solo, a manutenção das culturas e o arado de tração animal. Essas técnicas foram popularizadas através da seleção feita entre os camponeses, que obtiveram treinamento de um ano nos Centros de Aperfeiçoamento Rural (CPRs). Em outra parte do projeto, 500 hectares de terras de vale foram preparados para irrigação. Em 1984, o Projeto se expandiu dentro de novas orientações: os CPRs foram fechados, a diversidade das áreas delimitadas para a intervenção foi reconhecida e uma política de zoneamento foi introduzida. Uma abordagem que tinha como base o vilarejo foi desenvolvida e organizada com base em pesquisa e desenvolvimento. Esta reorientação, entretanto, não produziu os resultados esperados pelos agentes financiadores (a organização estatal francesa Caisse Centrale de Coopération estava envolvida nessa época) e o experimento foi interrompido em abril de 1988.

22. O termo "patamar agrotécnico" foi proposto por Bertrand: "após longos períodos de congelamento econômico, i.e., de determinismo, durante os quais os camponeses foram confrontados com estruturas ecológicas finitas, seguiram-se períodos de inovação e progresso, durante os quais novas possibilidades surgiram na exploração do meio ambiente.
Entretanto, a contribuição agrotécnica contém, em si mesma, seu próprio determinismo" (1975, p. 53).

23. Dumont (1986) cita o caso de uma camponesa da região de Niamey, que declarou que as mulheres de seu vilarejo estavam preparadas para praticar o controle de natalidade. Parece ser ainda muito cedo para fazer esta afirmação, mas não se deve pensar que sociedades camponesas "tradicionais" não se preocupam com esta questão. Nas áreas Haussa, há práticas de controle de natalidade que vêm de longa data, mas o seu propósito não é o de reduzir o número de nascimentos de crianças, mas sim o de evitar uma nova gravidez antes que a mulher tenha terminado o aleitamento de seu último filho. Entretanto, durante a pesquisa sobre as questões de saúde nas áreas urbanas, houve solicitação de pílulas anticoncepcionais, mesmo que ocasionalmente, de mulheres não escolarizadas, casadas e com filhos, provenientes de áreas rurais. Essas solicitações indicavam uma vontade explícita para limitar o número de filhos e, embora isso ainda não seja uma coisa comum ( 3 mulheres em 50 entrevistadas), ao menos testemunha a emergência tímida de novas atitudes em relação à fertilidade.

24. Não há dados sobre esta questão relacionando-a ao meio ambiente rural, mas resultados de uma sondagem urbana na cidade de Maradi colocam a taxa anual de nascimentos em $58,8 \%$ e o número médio de seis crianças nascidas vivas, por mulher (dados em fase de publicação).

25. Exceto durante a última fase do Projeto, quando a estocagem de cereais foi realizada em alguns vilarejos que haviam sido particularmente atingidos, após um grande êxodo rural provocado pela seca de 1984 .

26. Sobre este assunto, o vocabulário é bem explícito: o termo "filho" ( $d$ 'a) pode ser utilizado em Haussa para designar um empregado doméstico e, "filhos da (mesma) mãe" (y'an uwa) para companheiros.

27. Esse fenômeno da fragmentação das unidades domésticas foi estudado em detalhes em Raynaut, 1973.

28. Essa estratégia é acompanhada por uma modificação nos implementos utilizados, marcada pela introdução de instrumentos agrícolas tradicionais existentes em regiões vizinhas, permitindo que o trabalho seja concluído mais rapidamente (Raynaut, 1984).

29. A partir de 1984, o Projeto tentou levar em consideração a diversidade do ambiente humano. Uma síntese publicada em 1988 (Raynaut et al.) descreve essa tentativa. Entretanto, 
não foi possível conduzir a termo essa nova postura (ver abaixo, um resumo da história do Projeto).

30. Trata-se de estoques comunitários de grãos, de fertilizantes, de ações coletivas de preservação e da exploração das terras do vilarejo.

31. Em 1972, às vésperas da primeira grande seca, o imposto exigido por pessoa era o equivalente a mais de $100 \mathrm{~kg}$ de

\section{Bibliografia}

Banque Mondiale. La désertification dans les zones sahélienne et soudanienne de l'Afrique de l'Ouest, 1985.

Bernard, F. E. East of mount Kenya: Meru agriculture in transition. Weltforum verlag Monchen, 1972.

Bertrand, G. Pour une histoire écologique de la France rurale. In: Histoire de la France rurale, Seuil, 1975.

Bemardet, Ph. Pour une étude des modes de transmission. La technologie du manche court en Afrique Noire. Les instruments aratoires en Afrique Tropicale. La Jonction et le signe, Cahiers de l'ORSTOM, Série Sciences Humaines, 1984.

Billon, B. Le Niger à Niamey. Décrue et étiage 85. Cahiers de l'ORSTOM, série Hydrologie, 1984-85.

Boiral, P. et al. Paysans, experts et chercheurs en Afrique Noire. Karthala, 1985.

Bradley, P. N. Development Research and Energy Planning in Kenya. Ambio, 14(4-5), Royal Swedish Academy of Science, 1987.

Bradley, P. N. et al. Le Guidimaka Mauritanien. War on Want, 1977.

Coll. Campagnes marginales, campagnes disputées. Etudes Rurales, 71-72, 1978.

Comité Information Sahel. Qui se nourrit de la Jamine au Sahel. Maspero, 1974.

Commissariat Général au Développement (Niger). Avant-projet de Développement du Département de Maradi, 1972, multigr.

Copans, J. (Ed.). Sécheresses et Famines du Sahel. Maspero, 1975. milheto, ou seja, quase a metade da quantidade necessária para alimentar uma pessoa durante um ano (Raynaut, 1977).

32. Ver os dados apresentados por Mainet \& Nicolas, 1964.

33. Sobre o comportamento do Banco Mundial na década de 1970, ver as experiências relatadas por Dumont (1986).

34. Em particular, o sistema cooperativo foi apropriado pela burocracia local e por um punhado de notáveis.

Crozier, M.; Friedberg, E. L'acteur et le système. Seuil, 1977.

Dalby, D. et al. (Eds.). Drought in Africa. International African Institute, 1977.

Diarra, S. Les stratégies spatiales des éleveurs-cultivateurs peul du Niger central agricole. In: Maîtrise de l'espace agraire et développement en Afrique tropicale. Logique paysanne et rationalité technique. Mémoire ORSTOM n ${ }^{\circ}$ 89, 1979.

Dumont, R. Pour l'Afrique, j'accuse. Plon, 1986.

Egg, J. Mission d'appui sur le thème: le Nigeria et la stratégie alimentaire du Niger. INRA, 1987, multigr.

Franke, R.; Chasin. B. Seeds of Famine: Ecological destruction and the Development Dilemna in the West African Sahel. Alanheld \& Osmun, 1981.

Frère, J.-J. Enquête nationale sur la morbidité et la mortalité au Niger. Médecine d'Afrique Noire, 34(1), 1987.

Godelier, M. L'idéel et le matériel. Pensée, économies et sociétés. Fayard, 1984.

Grégoire, E. Etude socio-économique du village de Gourjae (Maradi). DGRST/Université de Bordeaux II, 1980.

Grégoire, E. Les Alhazai de Maradi (Niger). Histoire d'un groupe de riches marchands sahéliens. ORSTOM, Travaux et documents $n^{\circ} 187,1986$.

Gregory, J.; Piché, V. Mode de production et régime démographique. Journal Canadien d'Etudes Africaines, 1(1), 1985. 
Hyden, G. No Shortcuts to Progress: African Development Management in Perspective. University of California Press, Berkeley, 1983.

Koechlin, J. Rapport d'études sur le milieu naturel et les systèmes de production. DGRST Université de Bordeaux II, 1980.

Lebras, M. et al. Paludisme urbain et rural au Níger. Bulletin de la Société de Pathologie Exotique, 79, 1986.

Le Gal, P.-Y. Systèmes de production agricole et systèmes de culture. Projet de Développement de Maradi, 1984.

Lévi-Strauss, Cl. La pensée sauvage. Plon, 1962.

Mainet, G.; Nicolas, G. La vallée du Gulbi de Maradi, Enquête socio-économique. Etudes Nigériennes, n. 16, 1964.

Marchal, J.-Y. Lorsque l'outil ne compte plus. Techniques agraires et entités sociales au Yatenga. In: Les instruments aratoires en Afrique tropicale, op. cit., 1984.

Meillassoux, Cl. Femmes, greniers \& capitaux. Maspero, 1982.

Monod, J. Le hasard et la nécessité. Seuil, 1970.

Morin, E. La Méthode. 1 La nature de la nature. Seuil, 1977.

Morin, E. Sociologie. Fayard, 1984.

Nicolas, G. Un village bouzou du Níger. Etude d'un terroir. Cahiers d'Outre-Mer, T XV, 1962.

Nicolas, G. Dynamique sociale et appréhension du monde au sein d'une société hausa. Travaux et Mémoires de l'lnstitut d'Ethnologie - LXXVIII, 1975.

Polanyi, K.; Arensberg, C. Trade and Market in the Early Empires. Economies in History and Theory. Toe Free Press, N.Y., 1957 (ed. française, Les systèmes économiques dans l'histoire et dans la théorie, préface de M. Godelier. Larousse, 1975).

Raulin, H. La dynamique des techniques agraires en Afrique tropicale du Nord. Editions du CNRS, 1967.

Raynaut, Cl. Structures normatives et relations électives. Etude d'une communauté villageoise haoussa. Mouton, 1973.
Raynaut, Cl. Le cas de la région de Maradi. In: Copans, op. cit., 1975.

Raynaut, $\mathrm{Cl}$. Circulation monétaire et évolution des structures économiques shez les Haoussas du Níger. Africa, 47(2), 1977.

Raynaut, $\mathrm{Cl}$. Aspects socio-économiques de la préparation et de la circulation de la nourriture en pays haoussa. Cahier d'Etudes Africaines, 68, XVII-4, 1978.

Raynaut, $\mathrm{Cl}$. Synthèse des travaux effectués dans la région de Maradi. DGRST/Université de Bordeaux II, 1980.

Raynaut, Cl. (Ed.). Milieu naturel, Techniques et Rapports sociaux. Editions du CNRS, 1983.

Raynaut, $\mathrm{Cl}$. Outils agricoles de la région de Maradi (Níger). Les instruments aratoires en Afrique tropicale, op. cit., 1984.

Raynaut, $\mathrm{Cl}$. Disparités économiques et inégalités devant la santé à Maradi (Niger). Colloque Urbanisation et Santé dans le Tiers-Monde. ORSTOM, 1986.

Raynaut, $\mathrm{Cl}$. Conditions de vie et santé: le privilege urbain. Politique Africaine, n. 28, 1987a.

Raynaut, Cl. L'agricultnre nigérienne et la crise du Sahel. Politique Africaine, n. 28, $1987 \mathrm{~b}$.

Raynaut, $\mathrm{Cl}$. Aspects of the problem of land concentration in Níger. In: Downs and Reyna (Eds.). Land and Society in Contemporary Africa. University Press of New England, 1988.

Raynaut $\mathrm{Cl}$. et al. Le développement rural de la région au village. Analyser et comprendre la diversité. GRID/Université de Bordeaux, 1988.

Richards, P. Ecological Change and The Politics of African Land Use. African Studies Review, 26(2), 1983.

Sigaut, F. Essai d'identification des instruments à bras de travail du sol. In: Les instruments aratoires en Afrique tropicale, op.cit., 1984.

Stigliano, M. L'occupation agricole du sol dans le département de Maradi. DGRST/Université de Bordeaux II, 1980. 